${ }^{\circledR}$ Entomologica Fennica. 20 December 1995

\title{
Faunistics of Coleoptera in subarctic pine forests in Finnish Lapland
}

\author{
Anna-Liisa Sippola, Juha Siitonen \& Reino Kallio
}

Sippola, A.-L., Siitonen, J. \& Kallio, R. 1995: Faunistics of Coleoptera in subarctic pine forests in Finnish Lapland. — Entomol. Fennica 6:201-210.

The beetle fauna of pine forests was surveyed by window flight trapping in four separate study areas in Pallas-Ounastunturi National Park in Enontekiö Lapland $(L e)$ and Hammastunturi wilderness area in Inari Lapland $(L i)$. The total catch of individuals was 4905 , consisting of 195 species. The proportion of species new to the province was $48 \%$ in $L e$ and $25 \%$ in $L i$, respectively. Eleven rare species (known at most from 25 localities in Finland) were found. Rarefaction, diversity analyses and similarity indices showed that species richness, relative abundances of species and species composition did not differ significantly between the study areas.

Anna-Liisa Sippola, \& Reino Kallio, Arctic Centre, University of Lapland, P.O. Box 122, FIN-96101 Rovaniemi, Finland

Juha Sitonen, Finnish Forest Research Institute, P. O. Box 18, FIN-01301 Vantaa, Finland

Received 22 March 1994, accepted 25 April 1995

\section{Introduction}

Almost $15000 \mathrm{~km}^{2}$ of pristine areas were protected by the Wilderness Act in Finnish Lapland in 1991 (Suomen säädöskokoelma 62/1991). Over $80 \%$ of the area is comprised of barren oroarctic heaths, mires and mountain birch forests. Coniferous forests cover $12 \%$ of the total area; most of them ( $80 \%$ ) are pine (Pinus sylvestris) dominated. Spruce (Picea abies) dominated forests are found in southern parts of the wilderness areas, comprising $16 \%$ of the forest covered area. Birch (Betula pubescens) is present almost everywhere, but it seldom reaches the dimensions that are required for commercial use. The forests are mostly over 200 years old, and they have been largely intact except some smallscale local use. Most of the area, e.g. all the spruce- dominated forests, was set aside from forestry, but in a part of the pine forests (on about $200 \mathrm{~km}^{2}$ ) so called natural forest management is allowed (Erämaakomitean mietintö 1988).

Very little is known about the coleopteran fauna in the Finnish wilderness areas. No quantitative data and only a few species lists are available. Some relevant faunistic data can be found in Saalas (1917, 1923), Wegelius (1960) and Biström and Helve (1977). Records from Lapland are included in the lists on the distribution of species of some families: on bark beetles (Scolytidae) by Lekander et al. (1977), longhorn beetles (Cerambycidae) by Silfverberg and Biström (1981) and Chrysomelidae by Silfverberg (1987).

The aim of this study is (1) to provide basic faunistic data on coleopteran species in old, 


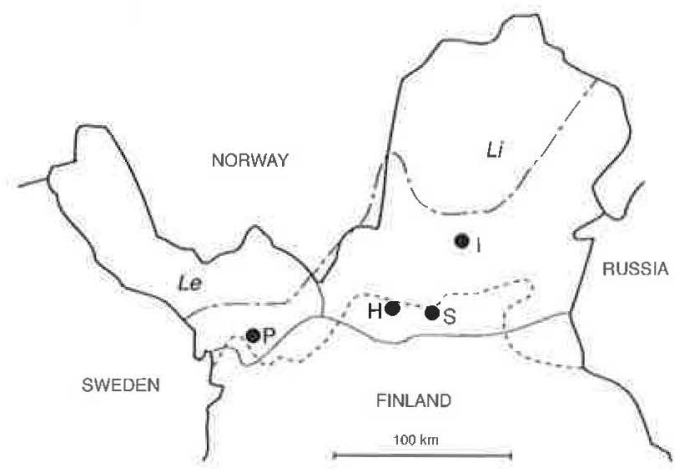

Fig. 1. Location of study areas $(P=$ Pallastunturi, $H=$ Härkäselkä, $S=$ Sotajoki, $I=$ Inari) and the boundaries of the biogeographical provinces $(L e=$ Enontekijö Lapland, $L i=$ Inari Lapland. Intermittent line $=$ northern limit of pine forest, regularly broken line $=$ northern limit of spruce forest.

subarctic pine forests, and (2) to explore diversity and variation of beetle assemblages between different areas in these forests.

\section{Material and methods}

\subsection{Study areas and sample plots}

We studied beetle fauna in four separate areas in Enontekiö Lapland $(L e)$ and Inari Lapland $(L i)$. Our study areas were located in Le: Pallas, uniform grid 757:37; Li: Härkäselkä, 759:46, 760:46; Li: Sotajoki, 758:47, 759:50; and in $L i$ : Inari, 764:49, 764:50 (Fig. 1). All the areas are situated near the northern limit of the spruce forests or north of it, Pallas within the Pallas-Ounastunturi National Park, Härkäselkä and Sotajoki within the Hammastunturi wilderness area, and Inari just outside of it (Fig. 1). Phytogeographically the area belongs to the northern boreal zone (Ahti, Hämet-Ahti and Jalas 1968).

Three sample plots of one hectar were established in each study area, making a total of twelve plots (Table 1). Total volume of living trees and the proportion of each tree species were measured on five relascope sample plots situated within the one hectare plot. Nine of the sample plots represented the most common forest type of the wilderness areas, which is pine-dominated dry forest, characterized by Vaccinium myrtillus and Empetrum nigrum in the ground layer (EMT, Kalela 1961). The second common site type is somewhat dryer with a larger proportion of Cladonia-species and Calluna vulgaris in the undervegetation (MCCIT). Three sample plots represented this site type (Pallas 1 and 2 and Inari 1). Birches were found as admixed trees in most areas, and in Härkäselkä spruces occurred in two sample plots. We tried to find sites with small, medium and large standing tree volume within each area (see Table 1).

\subsection{Sampling methods and period}

Window flight trapping was used as the sampling method. Six traps, which were set pairwise (one pair being a sampling unit), were used in each sample plot, one pair in the

Table 1. Site characters and number of window trap pairs in the sample plots. P1$\mathrm{P} 3=$ Pallas, $\mathrm{H}-\mathrm{H} 3$ = Härkäselkä, $11-13=$ Inari and S1-S3 = Sotajoki. Forest site types: $\mathrm{EMT}=$ Empetrum nigrum-Vaccinium myrtillus type, $\mathrm{MCClT}=$ Vaccinium myrtillus-Calluna vulgaris-Cladina type.

\begin{tabular}{lccrrrrr}
\hline $\begin{array}{l}\text { Sample } \\
\text { plot }\end{array}$ & $\begin{array}{c}\text { Height } \\
\text { from } \\
\text { the sea } \\
\text { level }(\mathrm{m})\end{array}$ & $\begin{array}{c}\text { Forest } \\
\text { site type }\end{array}$ & $\begin{array}{c}\text { Total } \\
\text { volume } \\
\text { of timber } \\
\left(\mathrm{m}^{3}\right)\end{array}$ & $\begin{array}{c}\text { Tree } \\
\text { species } \\
\text { composition } \\
\text { (\% of volume) } \\
\text { Pine Birch Spruce }\end{array}$ & $\begin{array}{c}\text { Number } \\
\text { of trap } \\
\text { pairs }\end{array}$ \\
\hline P1 & 330 & MCCIT & 57.1 & 100 & - & - & 3 \\
P2 & 310 & MCCIT & 95.9 & 100 & - & - & 1 \\
P3 & 295 & EMT & 117.1 & 100 & - & - & 3 \\
H1 & 300 & EMT & 58.0 & 93 & 7 & - & 3 \\
H2 & 330 & EMT & 54.9 & 86 & 9 & 5 & 1 \\
H3 & 330 & EMT & 47.9 & 37 & 26 & 37 & 3 \\
I1 & 220 & MCCIT & 51.6 & 92 & 8 & - & 3 \\
I2 & 200 & EMT & 65.0 & 98 & 2 & - & 1 \\
I3 & 240 & EMT & 145.2 & 100 & - & - & 3 \\
S1 & 310 & EMT & 42.4 & 94 & 6 & - & 1 \\
S2 & 300 & EMT & 60.2 & 95 & 5 & - & 1 \\
S3 & 220 & EMT & 66.9 & 94 & 6 & - & 1 \\
\hline
\end{tabular}


middle of the plot and the other two in the opposite comers of the plot. Only one trap pair in the middle of the sample plot was used in Sotajoki and in the sample plots with medium volume of timber (see Table 1). The trap was composed of a transparent acrylic window of $50 \times 50 \mathrm{~cm}$, under which a $67 \mathrm{~cm}$ long and $11 \mathrm{~cm}$ deep plastic flower pot was attached. The pots were filled with water up to the over-flow holes. Coarse salt $(\mathrm{NaCl})$ was used as the preserving agent, and some detergent was added to reduce the surface tension.

The trapping period was from the 5 th of June until the 15 th of September, 1992. The traps were emptied every third week.

\subsection{Calculations and statistical treatments}

Species richness was calculated as the mean number of species per trap pairs in each sample plot, to make different trapping efforts comparable. Fisher's $\alpha$ (Fisher, Corbet $\&$ Williams 1943) was used as the measure of alpha diversity, since this index is relatively little affected by sample size (Wolda 1983, Magurran 1988). Diversity was calculated as the mean diversity of the trap pairs in each sample plot. In addition, total species richness and diversity in each study area were calculated by pooling the catches of the three sample plots. Rarefaction (Simberloff 1978) was used to compare species richness between the study areas.

Renkonen's percentage index (Renkonen 1939) and Sørenses's index (Sørensen 1948) were used to describe similarities in species composition between the sample plots and the study areas. Renkonen's index values depend mostly on the relative abundances of abundant species, whereas Sørensen's binary index only takes into account the presence/absence of the species and, thus, is independent of relative abundances (Wolda 1981).

Differences in species richness and diversity between the study areas were tested by Kruskal-Wallis non-parametric test. A window trap pair was used as a sampling unit, and the diversities of all the trap pairs within each area were compared to the respective values in other areas.

\section{Results}

\subsection{Species found}

A total of 4905 individuals of 195 species were caught (Table 2, Appendix 1). The ten most abundant species comprised over $70 \%$ of the individuals in the pooled sample. These species form ecologically a mixed lot. Most of the abundant species were generalist predators belonging to the families Staphylinidae (Anthophagus omalinus 1005 individuals, Dimetrota aeneipennis
318 ex., Atheta procera 158 ex., Deliphrum tectum 127 ex.) and Cantharidae (Malthodes guttifer 684 ex., Absidia schoenherri 339 ex.). These species live as larvae on forest floor in litter or in decaying organic material. The larvae of other abundant species live on decaying birch (Anaspis arctica 230 ex.), on roots in forest soil (Eanus costalis 229 ex.) or in water pools (Cyphon variabilis $203 \mathrm{ex}$.). The larvae of Epuraea aestiva (241 ex.) live probably in nests of bumble bees. Most of the common species were found in all study areas. 92 species (47\% of all the species found) were represented only by one or two specimens.

Species new to the province were recorded as compared Lindroth (1960) and the later published literature that concerns these areas (Lekander et al. 1977, Biström \& Helve 1977, Silfverberg \& Biström 1981, Silfverberg 1987). Of the 89 species caught in Pallas, $43(48 \%)$ were new to the province $L e$, and of the 174 species caught in Härkäselkä, Inari and Sotajoki, $44(25 \%)$ were new to the province $\mathrm{Li}$.

Table 2. Numbers of individuals and species caught, species richness and alpha diversity in the sample plots and study areas. Species richness and alpha diversity in the sample plots are calculated as the means of the trap pairs in each plot.

\begin{tabular}{lrrr}
\hline $\begin{array}{l}\text { Sample plot/ } \\
\text { Study area }\end{array}$ & $\begin{array}{r}\text { Number of } \\
\text { individuals }\end{array}$ & $\begin{array}{r}\text { Species } \\
\text { richness }\end{array}$ & $\begin{array}{r}\text { Alpha } \\
\text { diversity }\end{array}$ \\
\hline P1 & 403 & 32 & 14.4 \\
P2 & 184 & 30 & 10.2 \\
P3 & 381 & 26 & 9.8 \\
P pooled & 968 & 89 & 24.2 \\
H1 & 748 & 34 & 10.5 \\
H2 & 292 & 46 & 15.4 \\
H3 & 1193 & 54 & 17.2 \\
H pooled & 2233 & 118 & 26.8 \\
I1 & 460 & 29 & 11.6 \\
I2 & 329 & 47 & 15.1 \\
I3 & 440 & 38 & 16.6 \\
I pooled & 1229 & 109 & 28.9 \\
S1 & 88 & 32 & 18.1 \\
S2 & 216 & 53 & 22.4 \\
S3 & 171 & 27 & 9.1 \\
S pooled & 475 & 78 & 26.5 \\
All the areas & 4905 & 195 & 41.1 \\
\hline & & & \\
\hline
\end{tabular}




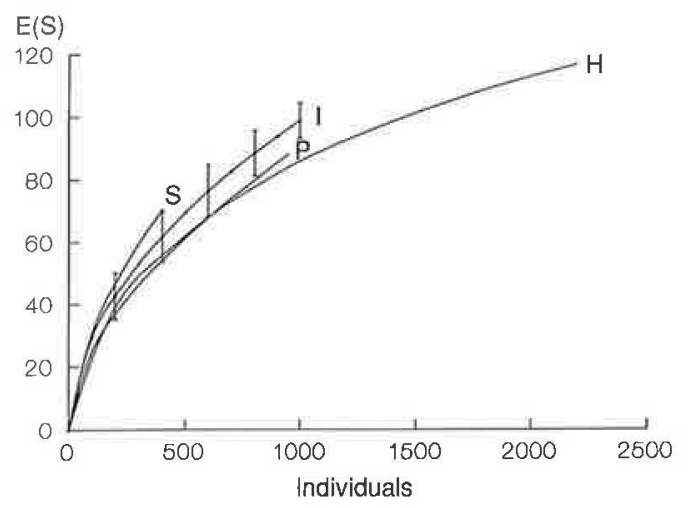

Fig. 2. Rarefaction curves of the pooled catches of the different study areas. $95 \%$ confidence limits indicated for Inari (I).

Eleven rare species (known at most from 25 localities in Finland, see Rassi 1993) were found: Hydnobius septentrionalis, Eudectus giraudi, Mycetoporus inaris, Tachinus atripes, Denticollis borealis, Ernobius longicornis, Stagetus borealis, Nephus bisignatus, Corticaria orbicollis, Orthocis linearis and Pityogenes saalasi.

Four species living on spruce (Xylechinus pilosus, Polygraphus punctifrons, Pityogenes saalasi and Dryocoetes autographus) were found exclusively in Härkäselkä, where spruce occurred (see Table 1). Several species living on decayed birch were found exclusively or most abundantly in Härkäselkä (e.g. Denticollis linearis, D. borealis, Triplax russica, Cis comptus and Rabocerus foveolatus). Some species living on birch were, however, found also in pure pine stands.

\subsection{Species richness, diversity and variation between the areas}

The number of species caught varied in the study areas from 89 in Pallas to 118 in Härkäselkä (the

Table 3. Similarities between the pooled catches of the study areas. Renkonen's percentage index values on the upper right face of the table and Sørensen's index values on the lower left face.

\begin{tabular}{lllll}
\hline Area & \multicolumn{1}{c}{$\mathrm{P}$} & \multicolumn{1}{c}{$\mathrm{H}$} & \multicolumn{1}{c}{$\mathrm{I}$} & $\mathrm{S}$ \\
\hline $\mathrm{P}$ & 1 & 0.49 & 0.41 & 0.45 \\
$\mathrm{H}$ & 0.53 & 1 & 0.51 & 0.64 \\
$\mathrm{I}$ & 0.55 & 0.57 & 1 & 0.50 \\
$\mathrm{~S}$ & 0.51 & 0.55 & 0.54 & 1 \\
\hline
\end{tabular}

total amount of species caught in Sotajoki can not be directly compared with the other areas because of the smaller sampling effort). Species richnesses and alpha diversities did not differ significantly among the study areas (richness: $\mathrm{H}=6.6, \mathrm{df}=3, \mathrm{p}>0.05$. n.s., diversity: $\mathrm{H}=3.4$, $\mathrm{df}=3, \mathrm{p}>0.05$, n.s.). Consistently, rarefaction analysis did not reveal any significant differences in species richness (Fig. 2).

The percentage similarities in species composition between the study areas varied from $40 \%$ (Inari-Pallas) to $64 \%$ (Härkäselkä-Sotajoki) (Table 3). The similarities counted by the Sørensen binary index varied from $51 \%$ (SotajokiPallas) to 57\% (Härkäselkä-Inari) (Table 3).

\section{Discussion}

The high proportion of species new to the province, especially in $L e$, shows that the beetle fauna in the subarctic forests in Finland is still poorly known. The fact that almost half of the species in the pooled catch were represented only by one or two specimens indicates that many more species could be caught with a greater trapping effort.

According to Lindroth (1960), the number of beetle species recorded from $L e$ is 438 and from Li 692. Since then, records on over 80 species new to these two provinces have been published. Unpublished records in $\mathrm{Li}$ exceed 200 species (J. Muona, personal communication). If we use the proportion of new species (i.e., species with no earlier published records) found in this study (48\% in $L e$ and $25 \%$ in $L i$ ) as an estimate of the number of unrecorded species in total, we can calculate that the rough estimate of the number of Coleoptera species in these provinces may be close to 700 in $L e$ and 900 in $\mathrm{Li}$. Some large data sets from more southern but phytogeographically comparable forest areas have been published in Sweden (Wiren 1945, 1947, Lundberg 1974, 1977). Lundberg reported a total of 1069 species found in the Messaure area, Lule Lappmark.

The small differences in the rarefaction curves and alpha diversities show that the species richness and abundance patterns within the same forest site type in subarctic pine forests are very similar. According to the species list and similarity indices, the species composition was rather similar in all the 
study areas. Tree species composition explains the occurrence of some saproxylic species (spruce and birch bound species). All the rare species found in our study have northern distribution in Fennoscandia (Lindroth 1960, Lundberg 1986), and their rarity (low number of known occurrences) may reflect the fact that northern areas are still poorly studied.

\section{References}

Ahti, T., Hämet-Ahti, L. \& Jalas, J. 1968: Vegetation zones and their sections in northwestern Europe. Ann. Bot. Fennici 5:169-211.

Biström, O. \& Helve, E. 1977: Koleopterologiska bidrag från Tana älvdal (Norra Finland). — Notulae Entomol. 57:83-84.

Erämaakomitean mietintö, 1989: - Komiteanmietintö [Committee Report] 1988:39. Helsinki. 238 pp. (in Finnish).

Fisher, R. A., Corbet, A. S. \& Williams, C. B. 1943: The relation between the number of species and the number of individuals in a random sample of an animal population. - J. Anim. Ecol. 12:42-58.

Kalela, A. 1961: Waldvegetationszonen Finnlands und ihre klimatischen Paralleltypen. - Arch. Soc. Zool. Bot. Fennicae Vanamo 16 Suppl. pp. 65-83.

Lekander, B., Bejer-Petersen, B., Kangas, E. \& Bakke, A. 1977: The distribution of bark beetles in the Nordic countries. - Acta Ent. Fenn. 32:1-37.

Lindroth, C. H. (ed.) 1960: Catalogus Coleopterorum Fennoscandiae at Daniae, — Entomologiska Sällskapet i Lund, $476 \mathrm{pp}$.

Lundberg, S. 1974: Skalbaggar funna i Messaureområdet, Lule Lappmark. 1 (Coleoptera), — Entomol. Tidsskr. 95:85-94.

- 1977: Skalbaggar funna i Messaureområdet, Lule Lappmark. 2 (Coleoptera). — Entomol. Tidsskr. 98:9194.

- ed.) 1986: Catalogus Coleopterorum Sueciae. Entomologiska Föreningen i Stockholm och Naturhistoriska Riksmuseet. Stockholm. 155 p.

Magurran, A. 1988: Ecological diversity and its measure- ment. - Princeton University Press, Princeton, New Jersey, 179 pp.

Rassi, P. (ed.) 1993: Frequency point enumeration of Finnish Coleoptera. - Maailman Luonnon Säätiö WWF Suomen Rahasto. Raportteja 6. WWH, Helsinki. 136 pp.

Renkonen, O. 1938: Statistich-ökologische untersuchungen über die tenestrische Käferwelt der Finnischen Bruchmoore. Ann. Zool. Soc. Zool. Bot. Fenn. Vanamo 6:1-231.

Saalas, U. 1917: Die Fichtenkäfer Finnlands I. - Ann. Acad. Sci. Fenn. A8, 547 pp.

- 1923: Die Fichtenkäfer Finnlands II. - Ann. Acad. Sci. Fenn. A22, 746 pp.

Silfverberg, H. \& Biström, O. 1981: Kartering av Finlands långhorningar (Coleoptera, Cerambycidae). - Notulae Entomol. 61:15-28.

Silfverberg, H. 1987: Mapping the Finnish Crysomelidae (Coleoptera). I. - Notulae Entomol. 67:5-16.

Simberloff, D. 1978: Use of rarefaction and related methods in Ecology. - In: Dickson, K. L., Caims, J. Jr. and R. J. Livingston (eds.): Biological data in water Pollution Assessment: Quantitative and Statistical Analyses. ASTM STP 652, pp. 150-165.

Suomen säädöskokoelma 1991: N:o 62. Erämaalaki, pp. 129-131. Helsinki.

Sørensen, T. A. 1948: A method of establishing groups of equal amplitude in plant sociology based on similarity of species content, and its application to analyses of the vegetation on Danish commons. - K. Danske Vidensk. Selsk. Biol. Skr. 5:1-34.

Wegelius, A. 1960: Bidrag till kännedomen om skalbaggsfaunan inom Pallas-Ounastunturi nationalpark. Notulae Entomol. 40:86-107.

Wiren, E, 1945: Bidrag till kännedomen om Coleopterafaunan i norra delen av det nordsvenska barrskogsområdet frăn insamlingar vid Pålkem. I. — Entomol. Tidskr. 66:24-43.

— 1947: Bidrag till kännedomen om Coleopterafaunan i norra delen av det nordsvenska barrskogsomrădet från insamlingar vid Pălkem. II. — Entomol. Tidskr. 68:189192.

Wolda, H. 1981: Similarity indices, sample size and diversity. - Oecologia 50:296-302.

- 1983: Diversity, diversity indices and tropical cockroaches. - Oecologia 58:290-298. 
Appendix. Species caught by window flight trapping in the four study areas. Number of specimens caught in each area $(P=$ Pallas, $\mathrm{H}=$ Härkäselkä, $I=$ Inari and $S=$ Sotajoki) are given. Species new to the provinces as compared to $L$ indroth (1960) and later published records are indicated $(E=L e, I=L i)$.

\begin{tabular}{|c|c|c|c|c|c|}
\hline Family/Species & $\mathrm{P}$ & $\mathrm{H}$ & 1 & $S$ & Prov. \\
\hline \multicolumn{6}{|l|}{ Carabidae } \\
\hline Calathus melanocephalus (Linnaeus) & 1 & - & - & - & \\
\hline Dromius agilis (Fabricius) & 4 & 5 & 1 & 1 & $\mathrm{E}$ \\
\hline \multicolumn{6}{|l|}{ Hydrophilidae } \\
\hline Helophorus flavipes (Fabricius) & - & 1 & - & - & I \\
\hline \multicolumn{6}{|l|}{ 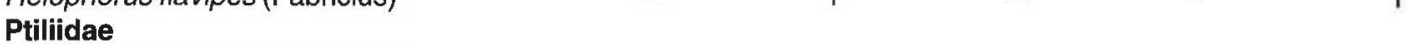 } \\
\hline Acrotrichis silvatica Rosskothen & - & - & 1 & _- & \\
\hline \multicolumn{6}{|l|}{ Leiodidae } \\
\hline Hydnobius septentrionalis Thomson & 1 & - & - & - & $\mathrm{E}$ \\
\hline Leiodes punctulata (Gyllenhal) & - & 2 & 1 & - & I \\
\hline L. inordinata (J.Sahlberg) & - & - & - & 1 & i \\
\hline Anisotoma axillaris Gyllenhal & - & 6 & 1 & 1 & \\
\hline A. castanea (Herbst) & - & 3 & 3 & 2 & \\
\hline A. glabra (Kugelann) & 2 & 5 & 2 & 1 & $E$ \\
\hline Agathidium confusum Brisout de Barneville & - & 2 & - & - & I \\
\hline A. arcticum Thomson & 1 & 13 & 10 & 2 & \\
\hline \multicolumn{6}{|l|}{ Cholevidae } \\
\hline Catops alpinus Gyllenhal & - & 21 & 3 & - & \\
\hline C. coracinus Kellner & - & - & 1 & & \\
\hline C. tristis (Panzer) & - & 1 & - & & \\
\hline C. nigrita Erichson & - & 1 & - & _- & 1 \\
\hline \multicolumn{6}{|l|}{ Staphylinidae } \\
\hline Philonthus puella Nordmann & - & 1 & - & - & 1 \\
\hline Quedius mesomelinus (Marsham) & - & 1 & 1 & - & 1 \\
\hline Q. plagiatus (Mannerheim) & - & 2 & 1 & 1 & \\
\hline Atrecus pilicornis (Paykull) & - & 6 & 1 & & \\
\hline Stenus geniculatus Gravenhorst & - & - & 1 & & \\
\hline Eusphalerum sorbicola(Y. Kangas) & 1 & - & - & - & $\mathrm{E}$ \\
\hline E. lapponicum (Mannerheim) & 1 & - & 2 & & \\
\hline Acrulia inflata (Gyllenhal) & 1 & 4 & 5 & 1 & \\
\hline Hapalaraea linearis (Zetterstedt) & 1 & 1 & 1 & - & $E, I$ \\
\hline Omalium rivulare (Paykull) & - & 3 & 4 & & \\
\hline O. strigicolle Wankowicz & & - & - & _- & 1 \\
\hline Phloeonomus lapponicus (Zetterstedt) & 1 & 2 & 2 & 1 & \\
\hline Deliphrum tectum (Paykull) & 3 & 48 & $7 \overline{6}$ & & \\
\hline Olophrum boreale (Paykull) & - & 1 & - & & \\
\hline Acidota crenata (Fabricius) & 4 & 4 & 1 & & \\
\hline Anthophagus alpinus (Paykull) & 11 & 1 & 1 & & \\
\hline A. omalinus Zetterstedt & 186 & 555 & 133 & 131 & \\
\hline Coryphium angusticolle Stephens & 67 & 1 & 2 & - & $\mathrm{E}$ \\
\hline Eudectus giraudi Redtenbacher & - & 1 & - & 1 & \\
\hline Scaphisoma agaricinum (Linnaeus) & - & - & 1 & - & \\
\hline S. subalpinum Reitter & - & - & - & 1 & \\
\hline Oxytelus laqueatus (Marsham) & - & 2 & - & 1 & 1 \\
\hline Mycetoporus monticola Fowler & - & - & 1 & - & \\
\hline M. lepidus (Gravenhorst) & 1 & - & 3 & 3 & E \\
\hline M. inaris Luze & - & 1 & - & - & \\
\hline Bryoporus punctipennis Thomson & 1 & - & - & - & E \\
\hline B. rugipennis (Pandelle) & 2 & 4 & - & 1 & \\
\hline Lordithon thoracicus (Fabricius) & - & - & 1 & - & \\
\hline
\end{tabular}


Appendix contnd.

\begin{tabular}{|c|c|c|c|c|c|}
\hline Family/Species & $\mathrm{P}$ & $\mathrm{H}$ & 1 & $S$ & Prov. \\
\hline L. speciosus (Erichson) & 1 & 5 & - & 1 & 1 \\
\hline Tachyporus obscurellus Zetterstedt & - & 1 & - & - & \\
\hline Tachinus rufipes (Linnaeus) & - & 1 & - & - & 1 \\
\hline T. pallipes (Gravenhorst) & - & 6 & 1 & - & \\
\hline T. proximus Kraatz & - & - & 16 & - & \\
\hline T. atripes J. Sahlberg & - & 2 & - & - & \\
\hline T. elongatus Gyllenhal & 1 & 11 & 6 & 3 & \\
\hline Aleochara moerens Gyllenhal & 1 & 5 & 72 & 3 & $\mathrm{E}$ \\
\hline Oxypoda spectabilis Märkel & - & 8 & 2 & 1 & 1 \\
\hline O. skalitzkyi Bernhauer & - & - & 1 & - & 1 \\
\hline O. umbrata (Gyllenhal) & - & - & - & 1 & I \\
\hline Acrostiba borealis Thomson & 1 & - & 1 & - & \\
\hline Ischnoglossa elegantula (Mannerheim) & 1 & 1 & - & - & $E, I$ \\
\hline Haploglossa marginalis (Gravenhorst) & 1 & - & - & - & $\mathrm{E}$ \\
\hline Phloeopora concolor (Kraatz) & 1 & - & - & - & $\mathrm{E}$ \\
\hline Atheta arctica (Thomson) & 1 & 1 & - & - & \\
\hline A. gyllenhalii (Thomson) & - & - & - & 1 & I \\
\hline A. subtilis (Scriba) & - & 1 & 3 & - & \\
\hline A. lateralis (Mannerheim) & - & - & 1 & - & \\
\hline A. sparreschneideri Munster & 2 & - & 1 & - & $\mathrm{E}$ \\
\hline A. cinnamoptera (Thomson) & - & - & 3 & 1 & \\
\hline A. aeneipennis (Thomson) & 13 & 78 & 216 & 10 & \\
\hline A. parapicipennis Brundin & 1 & 2 & - & 1 & $E, I$ \\
\hline A. lapponica J.Sahlberg & - & 21 & 56 & 1 & I \\
\hline A. altaica Bernhauer & - & 3 & - & - & \\
\hline A. laevicauda J.Sahlberg & 1 & - & 1 & - & I \\
\hline A. graminicola (Gravenhorst) & 1 & - & - & - & \\
\hline A. procera (Kraatz) & 12 & 72 & 44 & 30 & $\mathrm{E}$ \\
\hline A. allocera Eppelsheim & 1 & 1 & - & 1 & \\
\hline A. diversa (Sharp) & - & 2 & - & - & \\
\hline A. pilicornis (Thomson) & 1 & 1 & - & 1 & $E$ \\
\hline A. nigricornis (Thomson) & 3 & - & 1 & 1 & $\mathrm{E}$ \\
\hline A. picipes (Thomson) & 8 & - & - & - & E \\
\hline Anopleta corvina (Thomson) & - & 5 & - & - & \\
\hline Lyprocorrhe anceps (Erichson) & - & - & - & 1 & I \\
\hline Amischa nigrofusca (Stephens) & - & - & - & 1 & I \\
\hline Zyras humeralis (Gravenhorst) & 1 & - & - & - & $\mathrm{E}$ \\
\hline Bolitochara pulchra (Gravenhorst) & - & - & 1 & - & $\mathrm{I}$ \\
\hline \multicolumn{6}{|l|}{ Pselaphidae } \\
\hline Euplectus punctatus Mulsant & - & - & 1 & - & I \\
\hline \multicolumn{6}{|l|}{ Sphaeritidae } \\
\hline Sphaerites glabratus (Fabricius) & - & - & 1 & - & \\
\hline \multicolumn{6}{|l|}{ Scirtidae } \\
\hline Cyphon variabilis (Thunberg) & 14 & 186 & 3 & - & \\
\hline \multicolumn{6}{|l|}{ Scarabaeidae } \\
\hline Aphodius tenellus Say & 1 & 2 & 1 & 1 & $E$ \\
\hline A. lapponum Gyllenhal & 1 & 7 & 5 & 5 & \\
\hline A. piceus Gyllenhal & 1 & - & - & & \\
\hline Potosia cuprea (Fabricius) & 2 & 2 & - & - & $\mathrm{E}, \mathrm{I}$ \\
\hline Trichius fasciatus (Linnaeus) & 1 & 2 & - & - & $\mathrm{E}$ \\
\hline
\end{tabular}


Appendix contnd.

\begin{tabular}{|c|c|c|c|c|c|}
\hline Family/Species & $\mathrm{P}$ & $\mathrm{H}$ & 1 & S & Prov. \\
\hline \multicolumn{6}{|l|}{ Lycidae } \\
\hline Dictyoptera aurora (Herbst) & 1 & - & 1 & 1 & E \\
\hline Lygisopterus sanguineus (Linnaeus) & - & - & 1 & 1 & \\
\hline \multicolumn{6}{|l|}{ Cantharidae } \\
\hline Rhagonycha limbata Thomson & - & 1 & - & - & \\
\hline R. elongata (Fallén) & 55 & 1 & 3 & 1 & \\
\hline R. atra (Linnaeus) & - & 59 & - & 1 & \\
\hline Absidia schoenherri(Dejean) & 26 & 195 & 67 & 51 & \\
\hline Malthodes guttifer Kiesenwetter & 353 & 175 & 129 & 27 & \\
\hline M. mysticus Kiesenwetter & - & - & - & 3 & \\
\hline M. pumilus (Brébisson) & - & - & 1 & - & \\
\hline M. brevicollis (Paykull) & 1 & 2 & 17 & 3 & \\
\hline \multicolumn{6}{|l|}{ Elateridae } \\
\hline Athous subfuscus (Müller) & - & 3 & - & - & \\
\hline Harminius undulatus (Degeer) & - & 1 & - & - & \\
\hline Denticollis linearis (Linnaeus) & - & 4 & - & - & \\
\hline D. borealis (Paykull) & - & 3 & - & - & \\
\hline Liotrichus affinis (Paykull) & - & 26 & 3 & - & \\
\hline Orithales serraticornis (Paykull) & 1 & - & - & - & E \\
\hline Selatosomus impressus (Fabricius) & 3 & 4 & 1 & 1 & \\
\hline Eanus costalis (Paykull) & 32 & 116 & 45 & 36 & $\mathrm{E}$ \\
\hline Ampedus tristis (Linnaeus) & - & 1 & - & - & \\
\hline A. nigrinus (Herbst) & - & 9 & 14 & 4 & \\
\hline Sericus brunneus (Linnaeus) & 10 & 3 & 1 & 7 & \\
\hline \multicolumn{6}{|l|}{ Anobiidae } \\
\hline Ernobius longicornis (Sturm) & 1 & - & - & - & $\mathrm{E}$ \\
\hline Stagetus borealis Israelson & 1 & - & $\ldots$ & - & $\mathrm{E}$ \\
\hline \multicolumn{6}{|l|}{ Lymexylidae } \\
\hline Hylecoetus dermestoides (Linnaeus) & 3 & 13 & 1 & 6 & \\
\hline \multicolumn{6}{|l|}{ Melyridae } \\
\hline Aplocnemus tarsalis (Sahlberg) & 7 & 5 & 14 & 5 & $E, I$ \\
\hline Dasytes obscurus Gyllenhal & 1 & - & - & - & \\
\hline \multicolumn{6}{|l|}{ Nitidulidae } \\
\hline Epuraea angustula Sturm & 1 & 3 & 2 & - & $\mathrm{E}$ \\
\hline E. oblonga (Herbst) & - & 1 & - & - & \\
\hline E. boreella (Zetterstedt) & 4 & 11 & 30 & 1 & \\
\hline E. marseuli Reitter & - & - & 1 & & \\
\hline E. terminalis (Mannerheim) & - & - & 1 & 1 & \\
\hline E. silacea (Herbst) & 1 & 7 & 3 & 10 & $\mathrm{E}$ \\
\hline E. aestiva (Linnaeus) & & 14 & 213 & 9 & 5 \\
\hline E. rufomarginata (Stephens) & - & - & 2 & - & 1 \\
\hline Thalycra fervida (Olivier) & 1 & - & - & - & $E$ \\
\hline Gliscrochilus quadripunctatus (Linnaeus) & - & 1 & 2 & - & \\
\hline \multicolumn{6}{|l|}{ Rhizophagidae } \\
\hline \multirow{2}{*}{\multicolumn{6}{|c|}{ Cucujidae }} \\
\hline & & & & & \\
\hline \multicolumn{6}{|l|}{ Cryptophagidae } \\
\hline Cryptophagus lapponicus Gyllenhal & 14 & 18 & 14 & 2 & $\mathrm{E}$ \\
\hline C. instabilis Bruce & - & 3 & - & - & \\
\hline C. dorsalis Sahlberg & 4 & - & - & - & $\mathrm{E}$ \\
\hline Atomaria peltataeformis Sjöberg & 1 & - & - & - & \\
\hline Atomaria affinis (F. Sahlberg) & - & 1 & & & \\
\hline
\end{tabular}


Appendix contnd.

\begin{tabular}{|c|c|c|c|c|c|}
\hline Family/Species & $P$ & $\mathrm{H}$ & 1 & $s$ & Prov. \\
\hline Atomaria pulchra Erichson & 1 & 1 & 4 & 1 & \\
\hline \multicolumn{6}{|l|}{ Erotylidae } \\
\hline Triplax aenea (Schaller) & - & - & - & 1 & \\
\hline T. russica (Linnaeus) & - & 4 & 3 & 1 & \\
\hline T. scutellaris Charpentier & 1 & - & 3 & - & \\
\hline \multicolumn{6}{|l|}{ Cerylonidae } \\
\hline Cerylon histeroides (Fabricius) & - & 2 & 3 & - & \\
\hline C. ferrugineum Stephens & 2 & 3 & 5 & - & $\mathrm{E}$ \\
\hline \multicolumn{6}{|l|}{ Coccinellidae } \\
\hline Nephus bisignatus (Boheman) & - & 4 & - & 1 & 1 \\
\hline Calvia quatuordecimguttata (Linnaeus) & - & 2 & 1 & - & \\
\hline \multicolumn{6}{|l|}{ Latridiidae } \\
\hline Latridius consimilis Mannerheim & 2 & 20 & 1 & 1 & 1 \\
\hline Enicmus fungicola Thomson & - & 12 & 4 & 3 & \\
\hline E. rugosus (Herbst) & - & - & 1 & 1 & \\
\hline Corticaria lapponica (Zetterstedt) & - & 2 & 1 & - & \\
\hline C. orbicollis Mannerheim & 1 & - & 1 & - & \\
\hline C. abietorum Motschulsky & - & - & - & 1 & \\
\hline C. rubripes Mannerheim & - & - & - & 1 & \\
\hline C. ferruginea Marsham & 2 & - & 1 & - & $\mathrm{E}$ \\
\hline Corticarina obfuscata Strand & - & 1 & - & - & \\
\hline \multicolumn{6}{|l|}{ Cisidae } \\
\hline Cis comptus Gyllenhal & - & 2 & - & - & \\
\hline C. boleti (Scopoli) & - & - & 1 & 2 & \\
\hline Orthocis alni (Gyllenhal) & - & 2 & - & - & \\
\hline O. linearis (J.Sahlberg) & 2 & - & - & - & $\mathrm{E}$ \\
\hline \multicolumn{6}{|l|}{ Oedemeridae } \\
\hline Oedemera virescens (Linnaeus) & - & 1 & - & - & 1 \\
\hline \multicolumn{6}{|l|}{ Salpingidae } \\
\hline Rabocerus foveolatus (Ljungh) & - & 6 & - & 1 & 1 \\
\hline Salpingus ruficollis (Linnaeus) & 2 & 8 & 10 & 4 & $\mathrm{E}, \mathrm{I}$ \\
\hline
\end{tabular}

\section{Stenotrachelidae}

Stenotrachelus aeneus (Paykull)

Tenebrionidae

Bolitophagus reticulatus (Linnaeus)

Anaspidae

Anaspis arctica Zetterstedt

A. rufilabris (Gyllenhal)

Tetratomidae

Tetratoma ancora Fabricius

Melandryidae

Orchesia micans (Panzer)

Abdera triguttata (Gyllenhal)

Xylita laevigata (Hellenius)

6

$E, I$

Cerambycidae

Rhagium mordax (Degeer)

R. inquisitor (Linnaeus)

Oxymirus cursor (Linnaeus)

Anoplodera reyi (Heyden)

A. virens (Linnaeus)

Judolia sexmaculata (Linnaeus)

Monochamus sutor (Linnaeus)

$E$

E

I

I

(1)

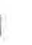

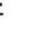


Appendix contnd.

\begin{tabular}{|c|c|c|c|c|c|}
\hline Family/Species & $P$ & $\mathrm{H}$ & 1 & $S$ & Prov. \\
\hline \multicolumn{6}{|l|}{ Chrysomelidae } \\
\hline Cryptocephalus pini (Linnaeus) & - & - & 1 & - & I \\
\hline Phratora polaris (Sparre Schneider) & - & 1 & - & 1 & \\
\hline \multicolumn{6}{|l|}{ Nemonychidae } \\
\hline Cimberis attelaboides (Fabricius) & 8 & - & - & 1 & $E, I$ \\
\hline \multicolumn{6}{|l|}{ Attelabidae } \\
\hline Deporaus betulae (Linnaeus) & 4 & 5 & - & 2 & I \\
\hline \multicolumn{6}{|l|}{ Curculionidae } \\
\hline Polydrusus ruficornis (Bonsdorff) & - & 32 & - & - & \\
\hline Anthonomus phyllocola (Herbst) & 1 & 1 & - & - & $E$ \\
\hline Rhynchaenus rusci (Herbst) & - & - & 1 & - & $\mathrm{I}$ \\
\hline Magdalis phlegmatica (Herbst) & 1 & - & 1 & - & $E, I$ \\
\hline M. duplicata Germar & 1 & - & 5 & - & E,I \\
\hline Hylobius abietis (Linnaeus) & - & - & 1 & & \\
\hline Pissodes validirostris (Sahlberg) & - & - & 1 & - & I \\
\hline \multicolumn{6}{|l|}{ Scolytidae } \\
\hline Hylurgops glabratus (Zetterstedt) & 2 & 5 & - & 1 & \\
\hline Hylastes brunneus Erichson & - & 1 & 2 & 2 & \\
\hline H. cunicularius Erichson & 1 & 6 & 2 & - & \\
\hline Xylechinus pilosus (Ratzeburg) & - & 1 & - & - & \\
\hline Tomicus piniperda (Linnaeus) & - & - & 2 & - & \\
\hline Polygraphus punctifrons Thomson & - & 2 & & - & \\
\hline Pityogenes saalasi Eggers & - & 1 & - & - & \\
\hline P. bidentatus (Herbst) & - & - & 1 & 4 & \\
\hline Dryocoetes autographus (Ratzeburg) & - & 4 & - & - & \\
\hline Trypodendron lineatum (Olivier) & 1 & - & - & - & \\
\hline Pityophthorus lichtensteinii (Ratzeburg) & 5 & 1 & 6 & 2 & \\
\hline
\end{tabular}

